\title{
In Memoriam
}

\section{Amin Banani}

1927-2013

AMIN BANANI, EMERITUS PROFESSOR OF HISTORY AND PERSIAN LITERATURE at UCLA, died July 28 in Santa Monica at the age of eighty-six. He was born in 1927 and graduated with a major in history from Stanford University in 1947. He obtained his MA from Columbia University in 1949 and returned to Stanford for his PhD, which he received in 1959. His academic career began in 1956 when he taught history at the Overseas Program of the University of Maryland in Athens, Greece, until 1958. He became an instructor at Stanford University and then taught as an assistant professor of humanities at Reed College from 1959 to 1961. From 1961 to 1963, he worked as a research fellow and assistant professor at Harvard University. In September 1963, he was invited to UCLA by Professor Gustav von Grunebaum to establish a program of Persian studies. Banani served on the Board of Directors of the Middle East Studies Association from 1972 to 1974, and on the Executive Council of the Society for Iranian Studies. He was vice president of the American Association of Iranian Studies. In 1989, he helped launch the Western world's first bachelor of arts program in Iranian studies. Banani once served as chair of the Department of Near Eastern Languages and Cultures and acting director of the Center for Near Eastern Studies.

Banani founded the Iranian Studies Program at UCLA, which over the years has earned a prominent reputation on campus and in the community. In addition to a BA, MA and PhD curricula which Banani helped establish, the program offers a wide range of courses spanning ancient Persian language, literature, literary criticism, philosophy, metrics, art history, and the religious and intellectual history of Islamic Iran. The program's library collection is one of the three richest and largest in the United States. UCLA's special holdings of immediate relevance to Iranian studies include several thousand manuscripts and other material in Arabic and Persian-from the first works on modern medicine in Persian to medieval philosophy, science, mathematics, astronomy, theology, jurisprudence, mysticism and literature. 
Banani is the author of The Modernization of Iran (1961) and editor and contributing author of The Epic of Kings (1967), Islam and Its Cultural Divergence (1971), Iran Faces the Seventies (1971) and Individualism and Conformity in Classical Islam, among numerous other publications.

He is survived by his wife Sheila Wolcott, daughters Susanne and Laila, and two grandchildren. $\&$

Editor

\section{Suad Muhammad Gamal}

1942-2013

IT IS WITH SADNESS WE ANNOUNCE THE PASSING OF SUAD MUHAMMAD GAMAL, on 19 May 2013. Suad served as Islamic Studies Librarian at Washington University in St. Louis from 1990 until her retirement in 2005. Responsible for reference, instruction, and collection development and management for Islamic and Near Eastern studies, she brought a wealth of knowledge, skills, and experience to Washington University. She was the library's first Islamic studies librarian and during her career at Washington University she took the initiative and did a remarkable job of building an impressive Islamic and Near East studies collection, including materials in Arabic, Persian, Turkish, and English. Suad was well respected and made enormous contributions not just to the library, but also to the intellectual life within the Islamic and Near Eastern studies community at Washington University, including providing bibliographic instructions at classes and serving as advisor to international student organizations. She was helpful, supportive, friendly, and cheerful, and devoted in her chosen profession. When travel became difficult she still managed to attend professional meetings and looked forward to being with her colleagues. Suad loved to share her deep faith and her love of Middle Eastern music and cooking.

Suad obtained her BA in Arabic Language and Literature from Cairo University in 1963, and her MA in Middle East History in 1981 and her MA in Library Sciences in 1984 from The University of Arizona. She worked in the Main Library of The University of Arizona for ten years before joining The Washington University Library in 1990. While serving on the library staff at The University of Arizona, due to her accumulated expertise, she trained newly 274 